Procyonidæ of the New World. The Eluropus is a large bear-like animal clad in snow-white fur. It inhabits the highest forests, and is called by the Chinese hunters "Pae-shioung" or "white bear." Its food is said to be of a vegetable character.

Proceeding to the Ungulates, we find other very remarkable discoveries recorded. The singular form Budorcas, hitherto only known from the Mishmee Hills of Assam, a large antilopine-looking creature with a pair of in-curved horns, is also met with in Moupin. Three new Nemorkedi, or goat-like antelopes, are also in the list. But perhaps the most interesting of all Père David's discoveries in this order of mammals is a new form belonging to the family Cervida, which M. Milne-Edwards has termed Elaphodus cephalophus. It is intermediate between the muntjacks and the true deer, having the highly developed upper canines of the former, but possessing a minute pair of horns about an inch in length, covered by a long tuft of frontal hairs as in the antelopes of the genus Cephalophus.

Altogether, out of the I ro species of mammals obtained by Père David in Moupin, no less than forty turned out to be new to Science, amongst which, as will be seen from what we have said above, were many of the most remarkable characters. There can be little question therefore, we think, that Moupin presents one of the most extraordinary faunas as regards its mammals that has become known to us for many years. It must be conceded that the land is difficult of access, and that perhaps no living European, except Père David, clad in Chinese garments, and speaking the ordinary vernacular of the country, could have found his way there. It has been lately stated in a scientific periodical that zoology is at a discount in France, and that their recent contributions to this science have been of the most meagre description. The splendid discoveries of Pere David, and the works of Alphonse Milne-Edwards in which they are described, are of themselves sufficient to refute such a baseless charge.

\section{THE TRANSIT EXPEDITIONS TO RODRIGUEZ AND KERGUELEN'S LAND}

SOME four years ago (NATURE, vol. i. p. 527), we directed attention to the desirable opportunity, presented by the Transic expeditions to several little-known spots in the Pacific, of sending out qualified Natural-History observers to the same islands, in order to obtain a knowledge of their flora and fauna. The astronomical stations selected as being especially worthy of this kind of research were the Sandwich Islands, Kerguelen's Land, and the Island of Rodriguez. This subject having been brought before the Council of the Royal Society last year, and thus to the notice of the Treasury, we are glad to be able to announce that, after certain little difficulties on account of the change of Government, the present ministry were induced to grant a sum of money sufficient to send out naturalists to two of these stations, and that arrangements are now being made for their speedy departure along with their astronomical brethren.

Three naturalists will proceed to Rodriguez, the most remote and least known of the Mascarene group of islands. Dr. T. B. Balfour, son of the well-known Professor of Botany of the University of Edinburgh, will devote himself to an examination of the general geological structure of this island, which presents features of the greatest interest, inasmuch as it forms one of the few exceptions to the general rule that all oceanic islands of the deep sea are of volcanic origin. Dr. Balfour will also collect the plants of Rodriguez so as to increase our acquaintance with the flora of the istand, which has hitherto, we believe, been scarcely touched.

Mr. George Gulliver, of the University of Oxford, has undertaken the zoological department, and will form as complete a series as possible of the recent animals of the island of every kind. The fauna of Rodriguez, as is well known, is excessively meagre, but it is very desirable that what little enclemic life there is left on it should be investigated and collected at once, as being the relics of a very peculiar phase of life which is now passing away very rapidly.

To Mr. Henry H. Slater, of the University of Cambridge, who has had good experience of cave-digging in the north of England, has been entrusted the task of the complete exploration of the limestone caverns of Rodriguez, which has been so ably commenced by Mr. Edward Newton, the Colonial Secretary of Mauritius, with successfal results well known to the majority of our readers. We trust also that Mr. Edward Newton may himself be able to accompany the party to Rodriguez, in order to give them the benefit of his advice and assistance. If this can be arranged, there remains no doubt that the Rodriguez expedition will attain most successful results.

For the expedition to Kerguelen's Land, the second point to which it has been agreed that natural history investigaton shall be directed, one naturalist has been considered to be sufficient, regard being had to the wellknown poverty of its flora and fauna, and to the fact that the Challenger expedition has paid, or will shortly pay, a visit to the island. For this post the Committee of the Royal Society has selected the Rev. A. E. Eaton, who has already distinguished himself by making excellent collections, both zoological and botanical, in Spitzbergen. Spitzbergen, as observed by Dr. Hooker, lies under somewhat similar conditions as regards climate in the northern hemisphere, to Kerguelen's Land in the southem, and there can be no doubt that a naturalist who has worked well in the former will have gained experience likely to assist him in the latter locality.

As regards the exact time of the departure of these two expeditions, we believe that nothing is yet finally settled; but it is probable that the naturalists will in each case depart in company with the astronomers, who are under orders to leave England in the course of the ensuing month.

\section{NOTES}

AT a meeting of Convocation of the University of London held on Tuesday evening last, a motion "That in the opinion of Convocation it is desirable that women should be permitted to take degrees in the University of London," was carried by a majority of 83 against 65 . The subject will, it is said, shortly be brought before the Senate, with whom originates all fresh legislation, Convocation having only a power of veto.

Ar the same meeting a motion urging the Senate not to permit the practice of vivisection to be carried on in the physiological laboratory of the Brown Institution under any circumstances except for medical or curative purposes, was lost by a majority of 59 against 16 .

WE have, on more than one occasion, spoken of the disgraceful way in which the Natural History Collections belonging to the defunct East India Company have been treated. They have been "boxed up" several years and deposited in the cellars of the India Office, so that they cannot be got at even when access to a particular type-specimen is requisite to enable a naturalist to determine a vexata qucstio. On the $5^{\text {th }}$ inst. Sir John Lubbock endeavoured to ascertain from the Under-Secretary for India whether there is any prospect of the grievance being remedied, but did not succeed in getting much more than the cautious reply that the subject was "under consideration." We believe, however, that there is really a negociation for the transfer of the whole of the collection to South Kensington, in accordance with the suggestion put forward in our article on this 